\title{
Keberkesanan Kaedah Pengurusan Fasiliti dan Penyumber Luaran Terhadap Prestasi Bangunan
}

\author{
Nordin Varseh Ismail*, Wan Nadzri Osman \\ Pusat Pengajian Pengurusan Teknologi dan Logistik, Universiti Utara Malaysia, Sintok, Kedah \\ *Corresponding author: anahusnid@yahoo.com
}

\begin{abstract}
Intense competition, higher wages, economic factors and the lack of internal labor, force organizations to look for alternatives to reduce costs and at the same time still maintaining existing performance. Similarly, the facility management of a building, especially involving government-owned buildings face the same phenomena. One popular method being used to overcome these phenomena is via outsourcing. Many organizations nowadays prefer to adopt outsourcing rather than internal contract practice. This resulted from the changes in the business environment that is focused towards effective operations.
\end{abstract}

Keywords: Facilities management, outsourcing, building performance

\begin{abstract}
Abstrak
Persaingan sengit, upah yang tinggi, faktor ekonomi dan kekurangan tenaga kerja dalaman memaksa sesebuah organisasi untuk mencari alternatif untuk mengurangkan kos dan dalam masa yang sama masih mengekalkan prestasi yang sedia ada. Begitu juga dengan pengurusan fasiliti sesebuah bangunan terutama sekali melibatkan bangunan milik kerajaan. Salah satu kaedah popular yang digunapakai adalah kaedah penyumberluaran. Organisasi pada masa kini lebih gemar mengamalkan kontak luar dari segi aktiviti perkhidmatan dari mempraktikkan kontrak dalaman. Ini telah di dorong akibat dari perubahan persekitaran perniagaan yang terarah pada operasi kerja yang lebih berkesan.
\end{abstract}

Kata Kunci : Pengurusan fasiliti, peyumber luaran, prestasi bangunan

(C) 2016 Penerbit UTM Press. All rights reserved

\subsection{PENGENALAN}

Menurut Fazira, Wan dan Soeb (2012), pengurusan fasiliti adalah proses yang melibatkan pencapaian objektif dan matlamat organisasi dengan memenuhi keperluan pelanggan, berusaha untuk meneruskan peningkatan dalam kualiti, mengurangkan risiko dan memastikan keuntungan. Kewujudan pengurusan fasiliti adalah untuk menyokong aktiviti organisasi yang mana ianya merupakan teras untuk mencapai matlamat organisasi (Fazira, Wan \& Soeb, 2012). Keberkesanan sesuatu sistem pengurusan fasiliti boleh dinilai berdasarkan pada pengukuran prestasi yang mana ianya adalah proses yang sistematik untuk mengukur kecekapan dan keberkesanan sesuatu sistem pengurusan ( Alexander, 2003). Justeru, pengurusan fasiliti telah berperanan sebagai salah satu dari fungsi strategi yang menyumbang ke arah perkembangan perniagaan yang positif serta meningkatkan kejayaan dan prestasi organisasi (Tucker \& Pitt, 2010). Pengurusan fasiliti dilihat sebagai satu opsyen yang boleh di praktikkan (Atkin, Brian \& Brooks, Adrian, 2000; Arnold \& Clive, 2005). Ini adalah kerana disiplin ini dapat diaplikasikan dalam pelbagai bidang pengurusan seperti pengurusan hartanah, pengurusan kewangan, pengurusan perubahan, pengurusan sumber manusia, pengurusan kontrak, pengurusan keselamatan dan kesihatan, pengurusan bangunan, pengurusan penyelegaran, perkhimatan domestik dan pembekal utiliti (Atkin, Brian \& Brooks, Adrian, 2000). Semenjak disiplin ini diperkenalkan sekitar tahun 1980an, ia secara konsisten telah di gunakan untuk mencapai kualiti pengurusan yang tinggi, pengurusan kos yang efektif dan berkesan serta pendekatan secara integrasi terhadap pengurusan bangunan (Pitt, \& Price, 2011). Maka, tidak hairanlah mengapa disiplin ini telah membangun secara drastik. Namun untuk mempraktikan disiplin ini, ia memerlukan masa serta kepakaran, kematangan dan kemahiran yang tertentu. Namun, kebanyakan organisasi tidak mempunyai kriteria tersebut (Hui \& Tsang, 2004). Maka salah satu caranya adalah dengan strategi penyumberan luaran.

\subsection{PENGURUSAN FASILITI}

Pengurusan fasiliti boleh dihuraikan sebagai proses menyediakan sokongan yang mantap pada operasi utama perniagaan serta menyumbang pada pencapaian objektif dan strategi sesebuah organisasi untuk memastikan bangunan, peralatan, perkhidmatan, sistem dan tenaga kerja yang efektif (Hamilton \& Norizan Ahmad, 2001). Kenyataan ini disokong oleh Zuhairi Abd. Hamid (2004) yang menyatakan bahawa pengurusan fasiliti dikenali sebagai pengurusan harta dan menyediakan perkhidmatan bagi menyokong operasi sesebuah organisasi. Pengurusan fasiliti bertanggungjawab mengkoordinasi keseluruhan usaha berkaitan merancang, rekaan dan pengurusan bangunan termasuk sistem, peralatan dan perabot untuk meningkatkan keupayaan organisasi bagi bersaing dalam perubahan dunia yang 
pesat (Kelly et al., 2005). Dari pandangan Grigg dan Jordan (1993) pula menekankan pengurusan fasiliti telah direka dalam tahun kebelakangan ini untuk menghuraikan pengurusan bangunan, infrastruktur dan perkhidmatan sokongan. Atkin dan Brooks (2000) berkata, pengurusan fasiliti adalah satu pendekatan bersepadu pada operasi, penyelenggaraan, peningkatan dan penyesuaian bangunan dan infrastruktur sebuah organisasi dengan tujuan mewujudkan satu persekitaran yang kuat menyokong objektif utama sesebuah organisasi.

Pengurusan fasiliti dilihat sebagai proses perancangan, pelaksanaan, penyelenggaraan dan mengambil kira kesesuaian ruang fizikal dan perkhidmatan untuk sesebuah organisasi, sekaligus mencari penjimatan kos berkaitan. Dari sudut kerjaya, menurut International Facility Management Association (2004), pengurusan fasiliti menggambarkan suatu kerja yang meliputi pelbagai disiplin bagi menjamin peranan alam bina dapat berfungsi melalui integrasi manusia, tempat, proses dan teknologi. Payant dan Lewis (1999) menambah operasi dan penyelenggaraan fasiliti adalah teras pada pengurusan fasiliti. Bagi mencapai kesemua fungsi pengurusan fasiliti, ia seharusnya bersesuaian dengan matlamat sesebuah organisasi dengan keperluan tenaga kerja yang mahir dan profesional.

\subsection{PENYUMBERLUARAN}

Menurut Kakabadse dan Kakabadse (2001) terdapat 4 faktor yang menyebabkan penyumberluaran dilakukan oleh organisasi, iaitu untuk :

i. Mencapai kelancaran operasi yang terbaik,

ii. Meningkatkan kos kemahiran pengurus,

iii. Meningkatkan kualiti perkhidmatan dan,

iv. Membantu pengurus agar dapat memberi tumpuan serta lebih fokus kepada matlamat teras organisasi.

Bagaimanapun, menurut Hui dan Tsang (2004) keputusan untuk menggunakan strategi penyumberluaran adalah sesuatu yang sangat kompleks serta amat berisiko. Akibat dari kelalaian pihak organisasi dalam membuat keputusan untuk tujuan penyumberluaran, terdapat beberapa kes, dimana strategi penyumberluaran telah menemui kegagalan dan akibat dari itu, organisasi terpaksa menanggung kos pembaikan yang sangat besar (Ikediashi, Ogunlana, \& Boateng, 2014).

Hui dan Tsang (2004) telah menegaskan bahawa terdapat empat jenis penyumberan strategik yang berkaitan dengan pengurusan fasiliti iaitu :

i. Penyumberan dalaman,

ii. Penugasan luaran,

iii. Penyumberan luaran terhadap penjimatan kos dan

iv. Penyumberan luaran terhadap keupayaan.

\subsection{OBJEKTIF KAJIAN}

Kajian ini bertujuan untuk:

i. Mengenalpasti tahap aplikasi pengurusan fasiliti dan peyumber luaran di bagunan milik kerajaan.

ii. Mengenalpasti sama ada wujud hubungan yang signifikan di antara pengurusan fasiliti dengan prestasi bangunan.

iii. Mengenalpasti sama ada hubungan yang signifikan di antara penyumberan luaran dengan prestasi bangunan.

iv. Mengenalpasti sama ada wujud hubungan yang signifikan di antara pengurusan fasiliti dengan prestasi bangunan apabila penyumberan luaran berperanan sebagai moderator.

\subsection{SIGNIFIKAN KAJIAN}

Kajian ini boleh digunakan dalam kapasiti akademik di mana kebolehannya untuk menganalisis piawaian semasa dan meramalkan serta mengjangkakan peningkatan pengurusan fasiliti dalam jangka masa yang pendek dan panjang. Selain itu, dapatan kajian juga akan dapat memberi gambaran secara kasar serta menjelaskan pelbagai faktor yang akan dihadapi dalam penyumberan luar yang berkaitan dengan pengurusan fasiliti. Hasil kajian ini juga dapat diaplikasikan dalam pelbagai disiplin terutamanya pengurusan kerana pengurusan fasiliti merupakan satu disiplin yang agak pragmatik. Pada masa yang sama, output kajian ini juga berupaya untuk menjelaskan proses pembuatan keputusan yang berkaitan dengan perolehan perkhidmatan pengurusan fasiliti. Selain dari itu, dapatan kajian juga dijangka mampu untuk :

i. Memberi ruang dan peluang kepada organisasi membuat penambahbaikan terhadap mutu pengurusan fasiliti dan seterusnya memberikan perkhidmatan yang terbaik kepada pelanggannya.

ii. Membuka peluang kepada penyelarasan antara agensi yang terlibat berbincang dan mencari kaedah yang terbaik dalam urusan dengan pihak ketiga (kontraktor).

iii. Memberi input kepada dasar kerajaan bagi membantu kontraktor bumiputera khususnya 


\subsection{KERANGKA TEORITIKAL KAJIAN}

Pembolehubah kajian

i. $\quad$ Pembolehubah bebas - Pengurusan Fasiliti

Menurut Then (1999) terdapat empat faktor yang perlu diambil kira dalam pengurusan fasiliti iaitu Perancangan Strategik Fasiliti, Pengurusan Strategik Aset, Pengurusan Aset Penyelenggaraan, dan Pengurusan perkhidmatan fasiliti.

ii. Pembolehubah bersandar - Prestasi Bangunan

Menurut, Yuhanis, Priyadarsini, \& Rabecca, (2013) terdapat tiga faktor yang digunakan untuk mengukur prestasi bangunan iaitu melibatkan faktor prestasi dari segi fungsi, impak, dan kualiti.

iii. Pembolehubah moderasi - Penyumberan Luaran

1.0 KERANGKA KAJIAN

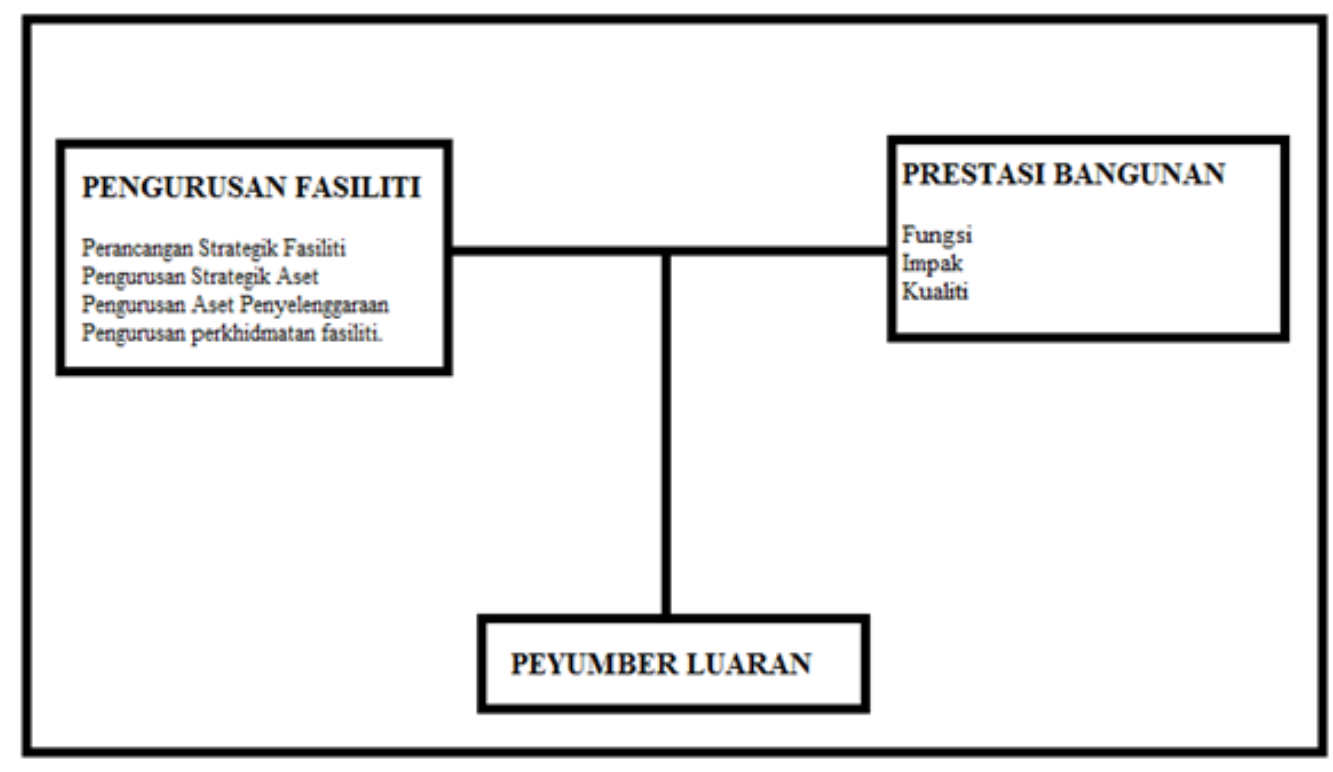

Rajah 1 Kerangka kajian

\subsection{KESIMPULAN}

Oleh kerana setiap strategi bergantung terhadap situasi serta keadaan yang spesifik, maka pemilihan kaedah pengurusan fasiliti yang bersesuaian adalah amat kritikal. Secara konvensional, perkhidmatan atau tugas pengurusan fasiliti dahulunya dilakukan secara dalaman. Akibat kekurangan sumber dan kepakaran dalaman organizasi, peyumber luaran dilihat sangat penting terutama sekali dalam aspek pengurusan failisiti. Tugas atau perkhidmatan tersebut pada masa kini telah dikontrakkan dengan kadar bayaran yang telah dipersetujui kepada pihak luar dan ianya diharap dapat meningkatkan prestasi sesebuah bangunan. Pendekatan baru iaitu dengan mengintegrasikan pengurusan fasiliti dengan strategi penyumberan ini dijangka mampu memberi kebolehsaingan dalaman organisasi.

\section{References}

Alexander, K. (2003). A Strategy For Facilities Management. Facilities, 21(11/12), 269-274.

Ancarani, A \& Capaldo, G (2005). Supporting Decision-Making Process In Facilities Management Services Procurement: a Methodological Approach. Journal of Purchansing and Supply Management, 11(5/6), 233-241.

Arnnold, W.L.K \& Clive, M.J.K. (2005). Optimisation of Performance in Facilities Management, Pacific Rim Real Estate society Conference, Melbourne, 24-25 January 2005.

Atkin, Brian \& Brooks, Adrian. (2000). Total Facilities Management. Oxford: Blackwell Science.

Cavana, R. Y., Delahaye, B. L., \& Sekaran, U. (2001). Applied Business Research: Qualitative And Quantitative Methods. New York: John Wiley \&Sons.

Fazira, S, Wan Zahari, W.Y.,\& Soeb, P. (2012). Users' Satisfaction Towards Facilities Management, FM desk in Public Higher Educational Institution in Malaysia. Advance in Management \& Applied Economics, 2(2), 58-69. 
Fuller, N. (2002). Beyond the core. Supply Management, 7(20), 39.

Hui, E.Y.Y. \& Tsang, A.H.C. (2004), "Sourcing Strategies Of Facilities Management", Journal of Quality in Management Engineering, 10 (2), 85-92.

Ikediashi, D.I., Ogunlana, S.O., \& Boateng, P. (2014). Determinants Of Outsourcing Decision For Facilities Management (FM) Services Provision. Facilities, $32(9 / 10), 472-489$.

Jones, Christine \& Jowett Valerie (1998). Managing Facilities, Oxford[England]; Boston: Butterworth-Heinemann.

Kakabadse, A. \& Kakabadse, N. (2001), "Outsourcing In The Public Services: A Comparative Analysis Of Practice, Capability And Impact", Public Administration and Development, 21(5),401-413.

Laporan Ketua Audit Negara Tahun 2012 Siri tiga, Jabatan Perdana Menteri.

Li, M. \& Choi, T. (2009). Traids In Services Outsourcing: Bridge, Bridge Decay And Bridge Transfer. Journal of Supply Management. 45(3), 27-39.

Natukunda, C.M., Pitt, M. \& Nabil, A. (2013). Understanding The Outsourcing Of Facilities Management Services in Uganda. Journal of Corporate Real Estate, $15(2), 150-158$

Pitt, M. \& Price, S. (2011). Implications of A Sustainability Policy For Facilities Management Organizations, Facilities, 29(9/10), 391-410.

Then, D.S.S. (1999). An Integrated Resource Management View Of Facilities Management. Facilities, 17(12/13),462-469.

Tucker, M. \& Pitt, M. (2010). Improving Service Provision Through Better Management And Measurement Of Customer Satisfaction In Facilities Management. Journal of Corporate Real Estate, 12(4), 220-233.

Tysdal, C. (1999). Order Take-Out And Get Back To Core Business Objectives. Communications News, 36(8), $24-24$.

Yuhainis, T. Priyadarsini, R. \& Rabecca, J.Y. (2013). Evaluation Of Building Performance For Strategic Facilities Management In Heakthcare. A Case Study Of A Public Hospital in Australia. Facilities, 31(13/14). 